\title{
Comparative studies on the mechanical properties and microstructures of outerwood and corewood in Pinus radiata D. Don
}

\author{
Ming-yue Li, Hai-qing Ren, Yu-rong Wang ${ }^{*}$, Ying-chun Gong and Yong-dong Zhou
}

\begin{abstract}
Twenty-year-old Pinus radiata trees imported from New Zealand were investigated, and a comparison was made between the outerwood (rings 16-20) and corewood (rings 4-6) in terms of mechanical properties, anatomical characteristics, microfibril angle (MFA), relative crystallinity, crystallite size and lignin content to determine the relationship between their mechanical properties and microstructures. The results demonstrated that the mechanical properties of the Pinus radiata outerwood were significantly better than those of the corewood. The outerwood had a modulus of rupture (MOR) of $106 \mathrm{MPa}$, a modulus of elasticity (MOE) of $11.4 \mathrm{GPa}$, and compressive strength parallel to the grain of $38.7 \mathrm{MPa}$, and the MOR, MOE and compressive strength parallel to the grain of the corewood were $78.9 \mathrm{MPa}, 7.12$ $\mathrm{GPa}$ and $29.3 \mathrm{MPa}$, respectively. The observed microstructures of the Pinus radiata outerwood and corewood were different, mainly due to differences in cell wall thickness, MFA, and relative crystallinity. The double wall thickness of the tracheid cells of the corewood and outerwood were 3.65 and $5.02 \mu \mathrm{m}$, respectively. The MFA data indicated that the average MFA of the outerwood was $14.0^{\circ}$, which was smaller than that of the corewood $\left(22.3^{\circ}\right)$. With X-ray diffraction, the relative crystallinity of the corewood was determined to be $35.7 \%$, while that of the outerwood was $40.2 \%$. However, the crystallite size of the outerwood cell wall shows no obvious difference from that of the corewood. Imaging FTIR spectroscopy showed a slightly higher relative content of lignin in the cell wall of the outerwood. The correlation between the microstructures and mechanical properties showed that the corewood with a thin cell wall, large MFA and low relative crystallinity had poor mechanical properties, while the outerwood with a thicker tracheid, smaller MFA and higher relative crystallinity had better mechanical properties. This means that the MFA, relative crystallinity and cell wall thickness synergically affect the mechanical properties of Pinus radiata in different radial locations.
\end{abstract}

Keywords: Pinus radiata, Outerwood, Corewood, Mechanical properties, Microstructures

\section{Introduction}

China is a country that engages in the export and consumption of wood products on a large scale, but it is also a country with relatively scarce forest resources. In recent years, with the increase in domestic timber cutting restrictions, China's timber dependence on foreign countries has increased significantly [1]. Pinus radiata is the main afforestation tree species in New Zealand, which

*Correspondence: yurwang@caf.ac.cn

Research Institute of Wood Industry, Chinese Academy of Forestry, Beijing 100091, China has the characteristics of rapid growth, straight wood grain, uniform structure, and strong stability, and is one of the most imported wood species in China in recent years [2]. Thus, research on the properties and processing technology of Pinus radiata has become one of the hotspots in the wood academic field.

There have been some studies conducted on imported Pinus radiata, which have mainly focused on processing and utilization [2], heat treatment modification [3] and the physical and mechanical properties [4]. Imported Pinus radiata usually has a large diameter, with an average diameter of $46 \mathrm{~cm}$ for trees 20 years old
Springer Open
C The Author(s) 2021. Open Access This article is licensed under a Creative Commons Attribution 4.0 International License, which permits use, sharing, adaptation, distribution and reproduction in any medium or format, as long as you give appropriate credit to the original author(s) and the source, provide a link to the Creative Commons licence, and indicate if changes were made. The images or other third party material in this article are included in the article's Creative Commons licence, unless indicated otherwise in a credit line to the material. If material is not included in the article's Creative Commons licence and your intended use is not permitted by statutory regulation or exceeds the permitted use, you will need to obtain permission directly from the copyright holder. To view a copy of this licence, visit http://creativecommons.org/licenses/by/4.0/. 
in previous research, and radial variations in the physical and mechanical properties of Pinus radiata have been preliminarily investigated $[4,5]$. For softwood, the concepts of juvenile versus mature wood, or corewood versus outerwood are usually used to discuss the radial variation in such properties [6-8]. Research on 17-year-old Pinus radiata from Chile and 11-year-old Pinus radiata from New Zealand showed radial variations in the modulus of elasticity (MOE), microfibril angle (MFA) and cell wall thickness $[9,10]$. Research on the properties of 27-yearold Pinus radiata from New Zealand showed that the density and MFA are significantly different between juvenile wood and all-wood composite [11]. For 13-year-old Pinus radiata from Australia there is a significant relation between MOE and age [12]. However, the mechanical properties and microstructures of different radial locations and their correlation in Pinus radiata have not been systematically reported.

The cell wall is the solid material of wood and the bearing structure of wood under stress. The anatomical structure, ultrastructure and the chemical composition of the cell wall affect the wood properties $[6,13$, 14]. Studies have shown that the variation in the cell wall thickness may become an important factor when analyzing the mechanical behavior of a wood cell [7]. As one of the important ultrastructural factors of the cell wall, the effect of MFA on the mechanical properties of wood is an important research topic. The change in MFA was found to be negatively correlated with the change in MOE, modulus of rupture (MOR) and hardness [9-11].

Different from the MFA, the crystallinity of the wood cell wall is positively correlated with the elastic modulus of wood. It was found that the decrease in the MOE of Chinese fir is related to the decrease in the crystallinity of the wood cellulose [15]. The correlation coefficient between the Populus tomentosa cell wall crystallinity and MOE was 0.75 [16]. In the model for predicting wood hardness, when the latter quantifier of crystallinity was not involved, the width and length of crystallites were consistently positively related to tangential and radial hardness but negatively related to transverse hardness [17], while the effect of crystallite size on other mechanical properties has not been reported.

As the substrate material of the cell wall, lignin is one of the factors that affects the elastic modulus of the cell wall, and lignin content is positively correlated with the elastic modulus of the cell wall $[18,19]$. In Gindl's research, the longitudinal modulus of elasticity was higher after the completion of lignification in Norway spruce [20], which explained why the MOE of the secondary wall of mature tracheids with high lignin content in spruce was $22 \%$ higher than that of immature tracheids [21]. In summary, the microstructures of wood have a significant impact on its mechanical properties, but the microstructural characteristics of 20-year-old Pinus radiata at different radial positions and how these structural characteristics affect the mechanical properties have not been reported.

Research on the differences between corewood and outerwood at the cell wall level is becoming important because it can clarify the macroscopic differences in the wood mechanics. The purpose of this study was: (1) to provide mechanical data, and microstructure characteristics and compare the differences between corewood and outerwood in 20-year-old Pinus radiata imported from New Zealand, and (2) to analyze the effect of microstructures on their mechanical properties through the revealed results from (1).

\section{Materials and methods Materials}

Logs $(5.9 \mathrm{~m})$ of Pinus radiata imported from New Zealand at the age of 20 were selected as experimental materials. Bolts $1.5 \mathrm{~m}$ in length were taken from six different logs for the measurements. A total of 6 bolts were measured. The sampling method is shown in Fig. 1. Two corewood (rings 4-6) and two outerwood (rings 16-20) strips were taken from each bolt. A total of 24 samples from the corewood and outerwood were used to perform the bending tests and compression tests. A $30 \mathrm{~mm} \times 20 \mathrm{~mm} \times 20 \mathrm{~mm}$ wood block was cut from the bending sample with a significant difference in mechanical properties. Three to five pieces were cut from the block for the MFA test, and the rest were ground into powder for the determination of the relative crystallinity and crystallite size. Wood blocks with dimensions of $10 \mathrm{~mm} \times 20 \mathrm{~mm} \times 20 \mathrm{~mm}$ were extracted from bending samples with significantly different mechanical properties for anatomical and chemical analysis.

\section{Mechanical properties testing}

24 samples with dimensions of $20 \mathrm{~mm}(\mathrm{R}) \times 20 \mathrm{~mm}$ $(\mathrm{T}) \times 300 \mathrm{~mm}(\mathrm{~L})$ were used to test the MOR and MOE according to standard procedures [22, 23]. 24 samples with dimensions of $20 \mathrm{~mm}(\mathrm{R}) \times 20 \mathrm{~mm}(\mathrm{~T}) \times 30 \mathrm{~mm}$ (L) were used to test the compressive strength parallel to the grain according to standard procedures [24]. Before testing, all the specimens were stored in a conditioning chamber $\left(20{ }^{\circ} \mathrm{C}\right.$ and $65 \%$ relative humidity) until they reached a moisture content of approximately $12 \%$. The samples were oven-dried immediately after testing, and the precise moisture content was determined by comparing the weights measured before and after drying. All the mechanical property values were subsequently adjusted to $12 \%$ moisture content using the methodology described in the relevant standard procedures [22-24]. 

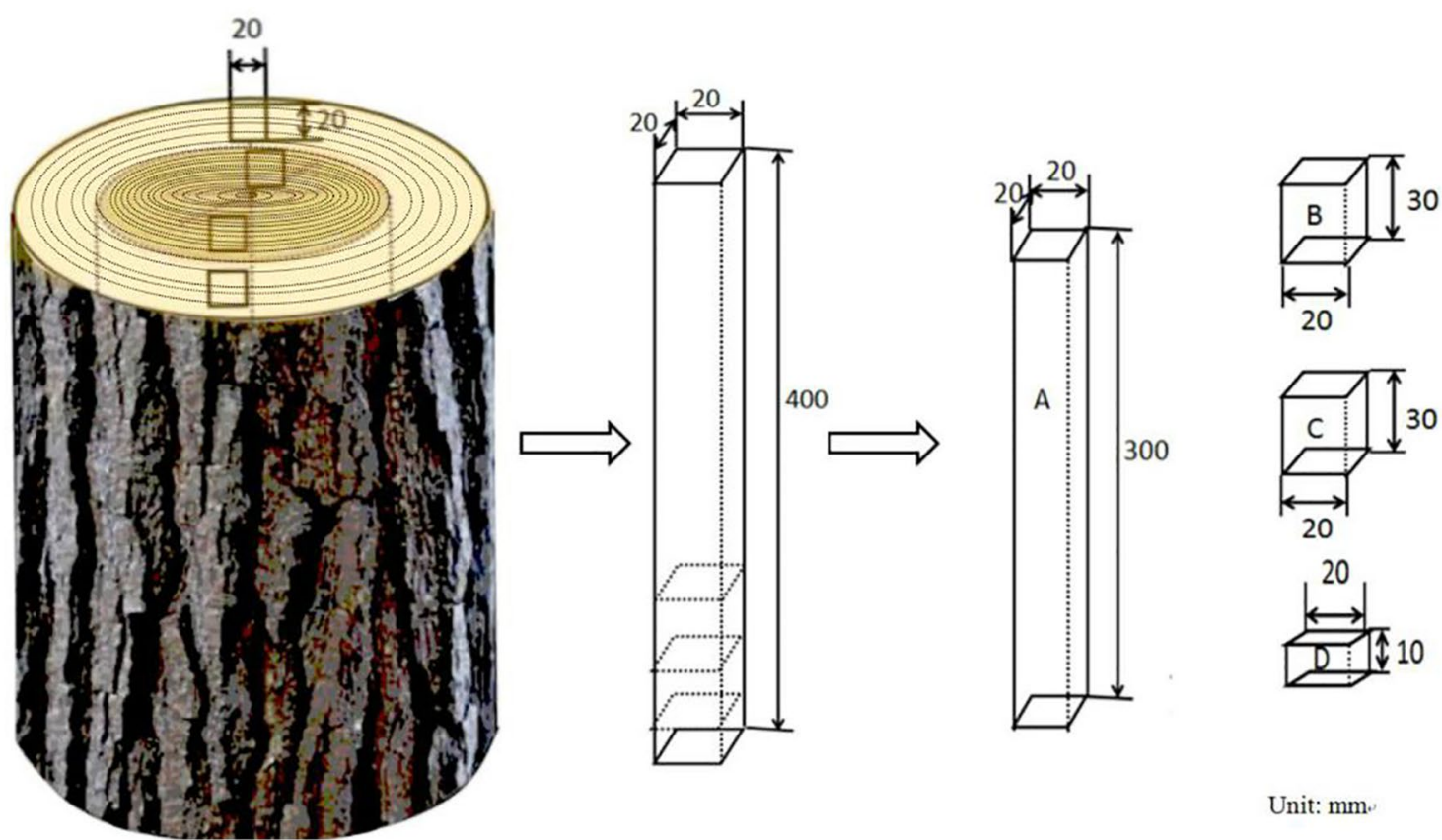

Unit: $\mathrm{mm}$

Fig. 1 Preparation of Pinus radiata samples. (A MOR and MOE. B Compressive strength parallel to the grain. C MFA, crystallite size, relative crystallinity. D Anatomical samples and chemical samples)

\section{Anatomical analysis}

To observe the anatomical structure, samples were transversely sectioned at a thickness of $15 \mu \mathrm{m}$ using a sliding microtome, and the sections were dehydrated through an alcohol series, stained with safranine for photography and observed using a ZEISS Imager A1 microscope (ZEISS, Germany). At the same time, at least 50 tracheids were chosen to measure radial cell wall thicknesses by Axiovision image processing software (Axiovision Release 4.6.3, Carl Zeiss, Germany).

\section{Crystallite size and relative crystallinity measurement}

An X-ray diffractometer (X'Pert Pro, Panalytical, Netherlands) was used to measure the crystallite size and relative crystallinity. For testing, the powdery samples were placed in a sample box, flattened and placed horizontally in the instrument. Measurements were performed with $\mathrm{CuK} \alpha$ radiation $(\lambda=1.541 \AA$, voltage $=40 \mathrm{kV}$, and current $=40 \mathrm{~mA}$ ). The step size was $0.02^{\circ}$, and the scanning speed was $4^{\circ} / \mathrm{min}$. The average width and length of the cellulose crystallites were calculated using Jade. The overlay of the measured curve and the fit curve were plotted, in addition to the estimated background and residual curve. Crystallite size estimation was done by using Scherrer's equation after correcting for instrument resolution:

$$
B_{\mathrm{hkl}}=\frac{K \lambda}{\cos \theta \sqrt{F \mathrm{whm}^{2}-\mathrm{inst}^{2}}},
$$

where $B_{\mathrm{hkl}}$ is the average size of the crystallites determined using hkl reflection, $K$ is a constant (0.9), $F$ whm is the full width at half-maximum of the reflection, inst is instrumental broadening, and a Gaussian function presenting the reflection and amorphous background was fitted to the measured intensity. The average width and the average length of the crystallites were determined from the 002 and 040 reflections, respectively.

The relative crystallinity was determined by fitting the theoretical intensity of the crystalline cellulose via reflections presented by the Gaussian function and amorphous background to the measured intensity curve. The relative crystallinity index $(C R)$ was determined as

$$
C R=\frac{I_{\text {tot }}-I_{\mathrm{amo}}}{I_{\text {tot }}},
$$

where $I_{\text {tot }}$ is the total experimental intensity and $I_{\text {amo }}$ is the intensity of the amorphous background.

The relative crystallinity was determined for a few selected samples from intensities measured using both symmetrical transmission and reflection geometries. The relative crystallinity was calculated as a weighted sum of the crystallinity values so that a weight of $2 / 3$ was used 
for the value determined from the intensity curve measured using symmetrical transmission and $1 / 3$ for the value determined from the intensity curve measured using symmetrical reflection geometry [25, 26].

\section{MFA determination}

An X-ray diffractometer (X'Pert Pro, Panalytical, Netherlands) was used to measure the MFA of the wood chip samples. The sample was rotated, and the intensity curve was measured as a function of the rotation angle $\phi$ with a step of $0.5^{\circ}$ and a measuring time of $180 \mathrm{~s}$ per point. A CuK $\alpha$ radiation source was used with $\lambda=0.154 \mathrm{~nm}$, voltage $=40 \mathrm{kV}$, and current $=40 \mathrm{~mA}$. The aperture of the incident beam was $2 \times 4 \mathrm{~mm}$. Mean MFA was determined according to the method developed by Cave [27], namely, 0.6 T, where $\mathrm{T}$ is an X-ray diffractometer parameter taken from the tangents drawn at the points of inflection $[28,29]$.

\section{Imaging FTIR spectroscopy}

To characterize the chemical differences in the cell walls of the tracheids, a Spectrum Spotlight 400 FTIR Imaging System (PerkinElmer Inc., Shelton, CT, USA) in attenuated total reflection mode was used. Slices approximately $14 \mu \mathrm{m}$ thick were cut by a sliding microtome, and a Fourier transform infrared microimaging system was used to detect the in situ transmission mode. Each sample was measured at 2 locations of the corewood and outerwood, and 3 regions were randomly selected at each location. In the analysis of the infrared spectral data, at least 15 points were selected from each region to produce corresponding infrared spectral images for analysis. Six areas were measured from each of the outerwood and corewood locations.

\section{Results and discussion}

Mechanical properties of outerwood and corewood Bending properties

The MOR and MOE are important indexes among the mechanical properties of wood. The MOR and MOE of Pinus radiata outerwood and corewood are listed in Table 1. By comparison, the MOR of the outerwood was
$34.9 \%$ higher than that of the corewood. Statistical analysis showed that there was a significant difference in the MOR of the corewood and outerwood, and the average MOR was $92.8 \mathrm{MPa}$.

The average MOE was $9.26 \mathrm{GPa}$. Table 1 shows that the MOE of the Pinus radiata outerwood was $60.1 \%$ higher than that of the corewood. Statistical analysis showed that there was a significant difference in the MOE results between the corewood and outerwood.

\section{Compressive strength parallel to the grain}

As shown in Table 1, the outerwood had a higher compressive strength than those of the corewood. Statistical analysis showed that there was a significant difference in the compressive strength, and the average compressive strength of the corewood and outerwood was 34.0 MPa. The compressive strength parallel to the grain indicates the maximum capacity of wood to bear the pressure load along the grain direction, which is an important basis for the selection of components that are mainly subjected to pressure [29]. Therefore, the outerwood had a better compressive ability than the corewood.

The corewood and outerwood were in the vicinity of the pith and bark of Pinus radiata, respectively. The results showed that the mechanical properties of the MOR, MOE and the compressive strength parallel to the grain of the outerwood were obviously better than those of the corewood, which is similar to the findings of Alonso's previous research [9], but contrary to the results observed for many hardwood species [30-32]. Attention should be given to the difference in mechanical properties between corewood and outerwood when processing and utilizing large-diameter Pinus radiata.

\section{The microstructures of outerwood and corewood}

\section{Anatomical characteristics}

Figure 2 shows the cross-sectional microstructures of the corewood and outerwood in Pinus radiata. The cell wall of the earlywood was large, and the cavity was ovoid, while the cell wall of the latewood was small and the

Table 1 Statistical analysis of the mechanical properties of Pinus radiata corewood and outerwood

\begin{tabular}{|c|c|c|c|c|c|c|c|}
\hline \multirow[t]{2}{*}{ Mechanics } & \multirow[t]{2}{*}{ Number of samples } & \multicolumn{2}{|c|}{ MOR (MPa) } & \multicolumn{2}{|c|}{ MOE (GPa) } & \multicolumn{2}{|c|}{$\begin{array}{l}\text { Compressive strength } \\
\text { (MPa) }\end{array}$} \\
\hline & & Mean & SD & Mean & SD & Mean & SD \\
\hline Outerwood & 12 & 106 & 20.8 & 11.4 & 2.47 & 38.7 & 7.48 \\
\hline Corewood & 12 & 78.9 & 9.69 & 7.12 & 1.36 & 29.3 & 3.34 \\
\hline$P$ & & $*$ & & * & & * & \\
\hline
\end{tabular}

${ }^{*} P<0.05$ showed a significant difference 

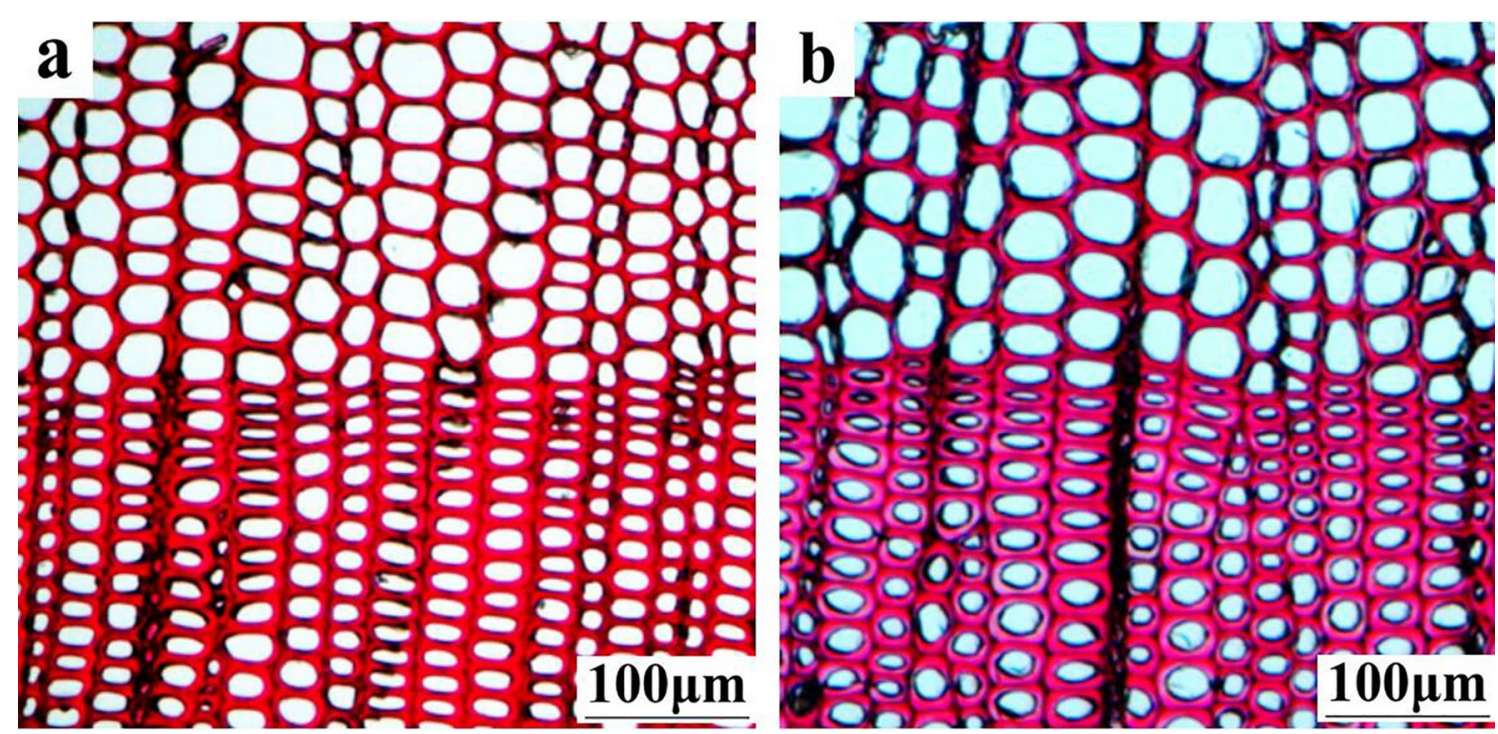

Fig. 2 The cross-sectional microstructures of the Pinus radiata corewood and outerwood (a corewood, b outerwood)

cavity was rectangular. The latewood cells of the outerwood were characterized by a small lumen and thick cell walls.

By measuring the radial double-wall thickness of tracheid cells of the corewood and outerwood of Pinus radiata, $3.65 \pm 0.45 \mu \mathrm{m}$ was obtained for the tracheid cells of the corewood, while $5.02 \pm 2.83 \mu \mathrm{m}$ was discovered for the tracheid cells of the outerwood. The results of variance analysis showed that there was a significant difference between corewood and outerwood. In previous study tracheids in ring 22 and ring 20 had significantly thicker cell walls than those in ring 7 of Pinus radiata [33]. The cell wall thickness at breast height of 19-year-old Pinus radiata rose by $57 \%$ from pith to bark [34] which agreed with our results in this study. The fiber wall thickness of poplar also increased gradually from the medulla to the bark [35]. The characteristics of low density $\left(452 \mathrm{~kg} / \mathrm{m}^{3}\right)$ of corewood and high density $(502 \mathrm{~kg} /$ $\mathrm{m}^{3}$ ) of outerwood in a previous study [5] were the same as the trend of cell wall thickness in this study.

\section{Relative crystallinity}

The diffraction patterns of the corewood and outerwood samples obtained by X-ray diffraction are shown in Fig. 3. Both the corewood and outerwood have three diffraction peaks near $18^{\circ}, 22.5^{\circ}$, and $35^{\circ}$ at $2 \theta$, corresponding to the (101), (002) and (040) crystal planes, respectively. For (002), the maximum diffraction is at approximately $2 \theta=22.5^{\circ}$, and the minimum value is at approximately $2 \theta=18^{\circ}$. The $\mathrm{X}$-ray diffraction patterns of the corewood and outerwood are basically the same,

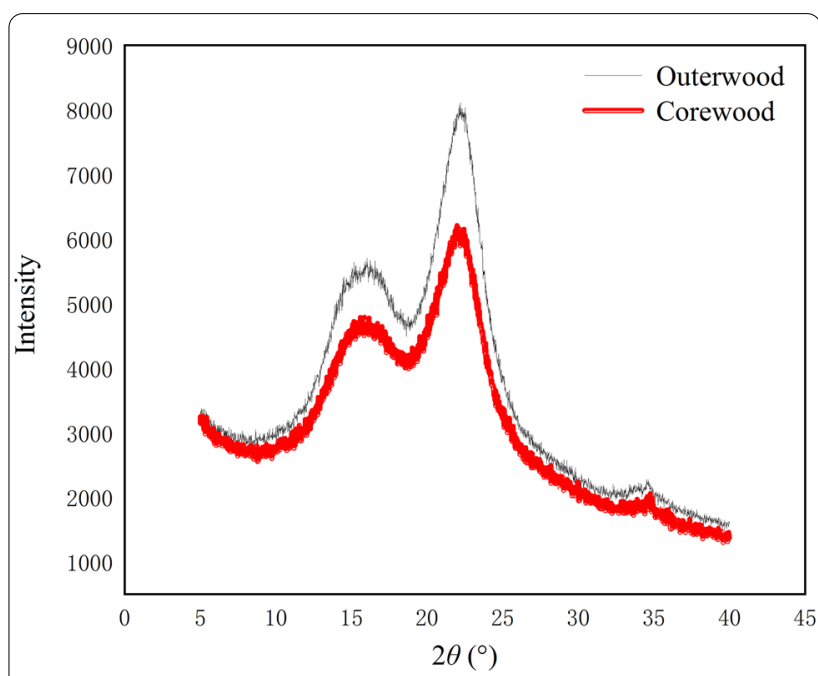

Fig. 3 X-ray diffraction chart of the Pinus radiata corewood and outerwood

but the peak strength of the two clones at $2 \theta=22.5^{\circ}$ are significantly different, and the full widths at halfmaximum are also different, indicating that the corewood and outerwood have the same cellulose crystal cells structure, while the degrees of crystallization are different. The values of the relative crystallinity of the outerwood and corewood are shown in Table 2. The results of the variance analysis showed that there was a significant difference in the crystallinity between the corewood and outerwood at the 0.05 level. The relative crystallinity of the outerwood was higher than that of the corewood. 
Table 2 The relative crystallinity and crystallite size of Pinus radiata outerwood and corewood

\begin{tabular}{llllll}
\hline Sample location & $\begin{array}{l}\text { Number of } \\
\text { samples }\end{array}$ & $\begin{array}{l}\text { Relative crystallinity } \\
\text { (\%) }\end{array}$ & Width (D002)/nm & Length (D040)/nm & $\begin{array}{l}\text { Aspect ratio } \\
\text { (D040/D002) }\end{array}$ \\
\hline Outerwood & 12 & $40.2 \pm 0.07$ & $2.14 \pm 0.23$ & $5.02 \pm 12.5$ & $2.36 \pm 0.34$ \\
Corewood & 12 & $35.7 \pm 0.04$ & $1.98 \pm 0.07$ & $5.38 \pm 15.1$ & $2.73 \pm 0.48$ \\
\hline
\end{tabular}

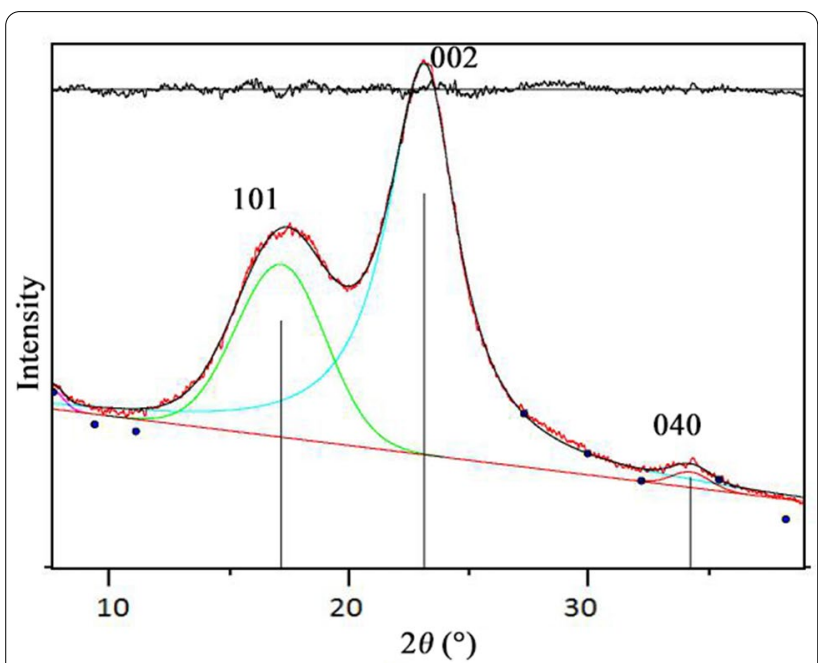

Fig. 4 The peak fitting diagram of $X$-ray diffraction results

\section{Crystallite size}

The peak segmentation fitting result of the X-ray diffraction data is shown in Fig. 4, and the curve has three characteristic peaks at $2 \theta=18^{\circ}, 22.5^{\circ}$, and $35^{\circ}$, corresponding to the (101), (002) and (040) crystal planes, respectively.

As illustrated in Table 2, the mean crystallite width of the outerwood was larger than that of the corewood, the mean crystallite length of the outerwood was smaller than that of the corewood, while the differences in both the width and length were not significant. The mean crystallite width was $2.06 \mathrm{~nm}$, slightly narrower than suggested in previous studies of 28-year-old Pinus radiata, $2.46 \mathrm{~nm}$, from the denser outer part of the stem [36]. The crystallite sizes of Norway spruce were found to be different in different studies, probably because of the differences in the ages and locations of the samples [25, 28]. Similarly, no obvious change in the crystallite width from pith to bark was reported by Andersson [25].

\section{Microfibril angle}

The X-ray diffraction patterns of samples from the corewood and outerwood are shown in Fig. 5. The measurement results showed that the mean MFA of the corewood was $22.3^{\circ} \pm 2.2^{\circ}$ and that of the outerwood was $14.0^{\circ} \pm 1.54^{\circ}$. The results of the variance analysis showed

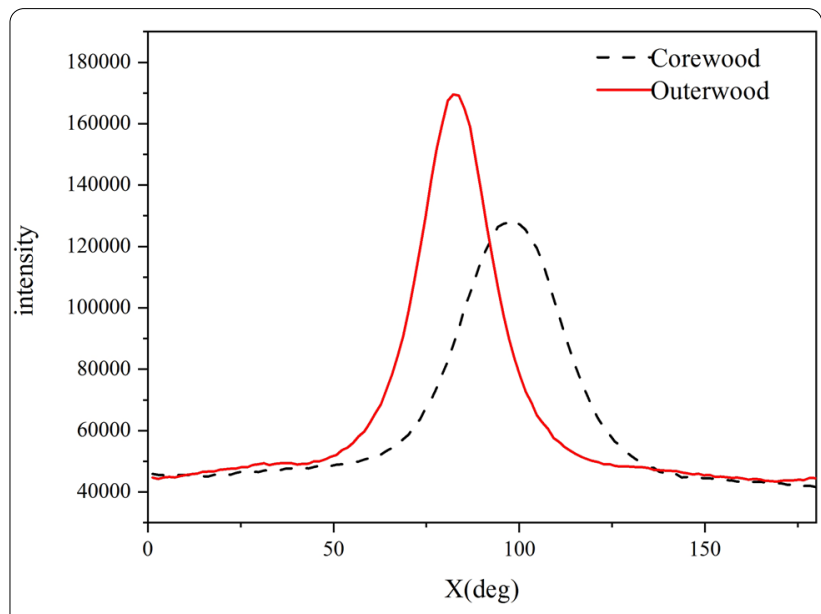

Fig. 5 X-ray of MFAs of the Pinus radiata corewood and outerwood

that there was a significant difference between the corewood and outerwood at 0.05 level.

In studies of wood from different tree species, such as Larix kaempferi and white oak, the results showed that the mean MFA decreased gradually from the core to the bark along the radial direction [37, 38]. In Donaldson's [39] study the MFA commonly showed larger values in the juvenile wood in the first few annual rings near the pith, followed by a decline to a more constant value in the mature wood. A study on the radial variation in MFA of Pinus radiata at 17 years old showed that the range of MFA from pith to bark was $30^{\circ}$ to $11^{\circ}$ [9]. The mean MFA of 8-month-old Pinus radiata was approximately $35^{\circ}$ in Brennan's study [40].

\section{Chemical composition}

In this study, infrared imaging was used to study the chemical composition of wood cell walls in situ, with an emphasis on the matrix materials. After obtaining the IR spectra of the cell wall, the average spectrum was baseline corrected at the absorption bands of 1800, 1548, 840 , and $785 \mathrm{~cm}^{-1}$ and normalized at $1424 \mathrm{~cm}^{-1}$, corresponding to the $\mathrm{CH}_{2}$ symmetric bending vibration of the $\mathrm{CH}_{2}-\mathrm{OH}$ group in cellulose.

For lignin, the aromatic skeletal vibrations, together with the $\mathrm{C}=\mathrm{O}$ stretch at $1598 \mathrm{~cm}^{-1}$, the aromatic skeletal vibration at $1510 \mathrm{~cm}^{-1}$, and the methoxyl $\mathrm{C}-\mathrm{H}$ bending 
band at $1366 \mathrm{~cm}^{-1}$ were analyzed. Compared to the corewood, the outerwood showed an apparent increase in absorbance at $1510 \mathrm{~cm}^{-1}$, while the absorbance at 1598,1650 and $1366 \mathrm{~cm}^{-1}$ was only marginally different (Fig. 6). The lignin types in the corewood and outerwood are the same. The increase in aromatic rings may be due to the higher lignin content in the outerwood. In Yang's [41] study, the lignin structure of the 20-year-old Pinus radiata corewood was the same as that of the outerwood, and the lignin content of the outerwood was slightly higher than that of the corewood.

\section{Correlation between microstructures and mechanical properties}

In this study, the mechanical properties of the Pinus radiata corewood and outerwood were studied to provide basic data for their efficient utilization. Additionally, their microstructures, described by factors such as their anatomical parameters, relative crystallinity, crystallite size and MFA were explored. Some microstructures were significantly different, which provided a comprehensive description of the reason for the difference in the mechanical properties of Pinus radiata corewood and outerwood.

\section{The relationship between anatomical parameters and mechanical properties}

Wood is a material composed of a variety of cell types. The cell walls are the solid material of wood and the loadbearing structure of wood under stress. By comparing the microstructures of the Pinus radiata corewood and outerwood, it was found that the outerwood with a thicker cell wall, had a higher MOR, MOE and compressive strength parallel to the grain, while the corewood with a thinner cell wall had poorer mechanical properties.

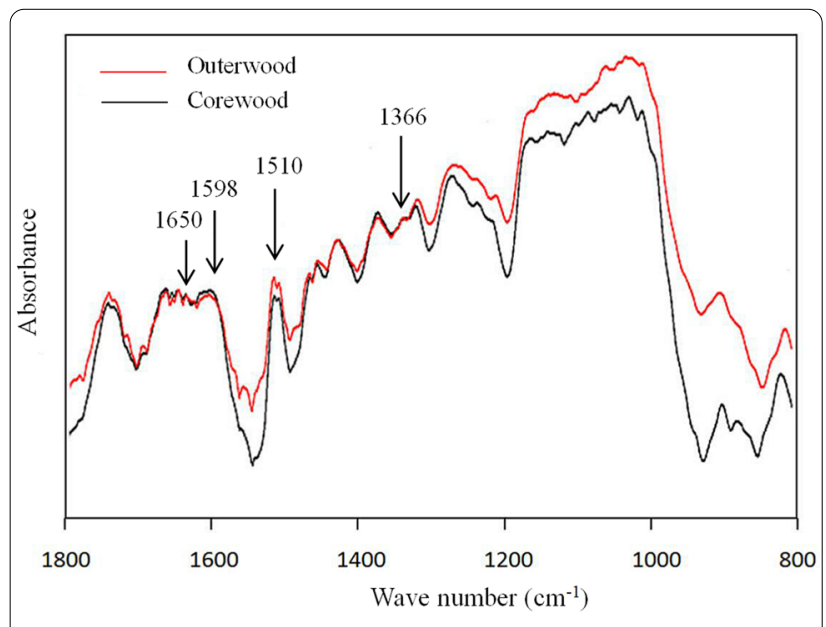

Fig. 6 FTIR spectra of the Pinus radiata outerwood and corewood
Tracheid wall thickness was positively correlated with the mechanical properties of Pinus radiata, indicating that the anatomical parameters may affect the mechanical properties at different radial locations in Pinus radiata.

\section{The relationships among relative crystallinity, crystallite size, and mechanical properties}

The growth process of trees is the process of the gradual accumulation of cellulose base fiber and an increase in crystallinity. By comparing the relative crystallinity and mechanical properties of corewood and outerwood, we found that with a higher relative crystallinity of the outerwood, the MOR, MOE and compressive strength parallel to the grain increased, whereas with a lower relative crystallinity of corewood, the MOR, MOE and compressive strength parallel to the grain decreased. Thus, the relative crystallinity could be a structural factor that affects the mechanical properties of Pinus radiata corewood and outerwood. As the relative crystallinity of cellulose increases, the binding forces between the molecular chains are strengthened and the orientation of the fibers becomes more favorable, which enhances the mechanical properties of most woods. Previous studies have shown that the degree of relative crystallinity is positively correlated with the dimensional stability and tensile strength of wood $[9,42]$.

The width and length of the crystallites were consistently positively related to the tangential and radial hardness, but negatively related to the transverse hardness in Damayanti's [17] study. However, there was no significant difference in crystallite size found between the corewood and outerwood. Hence, the crystallite size is not the main factor affecting the bending properties and compressive strength parallel to the grain in this species of tree.

\section{The relationship between MFA and mechanical properties}

In this study, the mechanical properties MOR, MOE and compressive strength parallel to the grain of the Pinus radiata outerwood, were all higher than those of the corewood, while the MFA of the outerwood was lower than that of the corewood. This means that the MFA is negatively correlated with the mechanical properties, which is consistent with the conclusion of previous studies [33, 38, 43]. The arrangement of cellulose microfibrils in the cell walls plays a major role in determining the mechanical performance and shrinkage anisotropy of wood $[44,45]$. The mechanical properties of outerwood are better than those of corewood in Pinus radiata. Thus, MFAs have an important influence on the mechanical properties of Pinus radiata. 


\section{The relationship between lignin and mechanical properties} Lignin is a high-molecular-weight aromatic polymer in the cell wall of trees and is one of the three components of the cell wall. Comparing the lignin of corewood and outerwood and the mechanical properties of wood, it was found that the outerwood had a slightly higher lignin content and a higher MOE, MOR and compressive strength parallel to the grain. Previous studies have shown that lignin is packed into the cellulose skeleton and plays an important role in enhancing the mechanical strength of plants and maintaining the normal morphology of cells [46]. In a developing cell wall, cellulose fibrils coated with hemicellulose form an open network, whose empty spaces are progressively filled up with lignin [44, 47]. In this study, the lignin content may be an influencing factor of the mechanical properties of Pinus radiata, but not the major factor.

\section{Conclusions}

In this paper, a comparison was performed between the outerwood and corewood of Pinus radiata in terms of their mechanical properties and microstructures. The results showed that the MOR, MOE and compressive strength parallel to the grain of the Pinus radiata outerwood were greater than those of the corewood, by 34.9, 60.1 and $32.3 \%$, respectively. The relative crystallinity and the cell wall thickness of outerwood were 37.5 and $12.8 \%$ greater than those of the corewood, respectively. The MFA of the outerwood was $37.1 \%$ smaller than that of the corewood. FTIR spectroscopy images showed that the chemical composition and structure had no obvious change between the corewood and outerwood, but a slightly higher relative content of lignin was found in the cell walls of the outerwood. The crystallite size was not significantly different between the corewood and outerwood. The corewood and outerwood mechanical properties were positively correlated with the relative crystallinity and cell wall thickness, while, the MFA was negatively correlated with the mechanical properties. The synergy of these factors influence the mechanical properties of wood.

\section{Abbreviations \\ MFA: Microfibril angle; MOR: Modulus of rupture; MOE: Modulus of elasticity; CR: Crystallinity index.}

\section{Acknowledgements}

The authors wish to thank to Xin Gao (Chinese Academy of Forestry, China) and Yanhua Wu (Chinese Academy of Forestry, China) for their assistance with the experimental material collection and mechanical experimentation, respectively.

\section{Authors' contributions}

ML: investigation and manuscript writing. YW: investigation, supervision, project administration, funding acquisition. HR: manuscript revision, supervision, funding acquisition. YG: manuscript review and editing. YZ: manuscript revision and funding acquisition.

\section{Funding}

This work was supported by the National Natural Science Foundation of China (31971596), National Key Research and Development project of China (2017YFD0600201) and the Central Public Interest Scientific Institution Basal Research Fund (CAFYBB2017ZC003).

\section{Availability of data and materials}

The data used to support the findings of this study are available from the corresponding author upon request.

\section{Declarations}

\section{Competing interests}

The authors declare that they have no known competing financial interests or personal relationships that could have appeared to influence the work reported in this paper.

Received: 28 August 2020 Accepted: 10 October 2021

Published online: 20 October 2021

\section{References}

1. Zhou YD (2019) Wood Properties and processing technology of radiata pine and mahogany (in Chinese). China Wood Ind 33(1):1-4. https://doi. org/10.19455/j.mcgy.20190101

2. Gao X, Zhou F, Fu Z (2019) Current status and suggestions for primary processing of imported radiata pine timber in China (in Chinese). China Wood Ind 33(01): 5-7+12. doi: https://doi.org/10.19455/j.mcgy.20190102

3. Fu ZY, Zhou YD, Gao X, Liu HH, Zhou F (2019) Changes of water related properties in radiata pine wood due to heat treatment. Constr Build Mater 227(10):116692.1-116692.7. https://doi.org/10.1016/j.conbuildmat. 2019.116692

4. Wu YH, Sun HY, Ren HQ, Zhou YD, Wu ZHK, Wang YR (2019) Physical and mechanical properties of imported Pinus radiata wood (in Chinese). China Wood Ind 33(2):48-50. https://doi.org/10.19455/j.mcgy.20190211

5. Wang YR, Wu YH (2019) Study on radial variation of main physical properties of imported Pinus Radiata wood (in Chinese). J For Eng 4(6):48-53

6. Burdon RD, Paul KR, Walker JCF, Megraw RA, Robert E, Cown DJ (2004) Juvenile versus mature wood: a new concept, orthogonal to corewood versus outerwood, with special reference to Pinus radiata and $P$. taeda. For Sci 50(4):399-415. https://doi.org/10.1093/forestscience/50.4.399

7. Watanabe U, Norimoto M, Morooka T (2000) Cell wall thickness and tangential young's modulus in coniferous early wood. J Wood Sci 46:109-114. https://doi.org/10.1007/BF00777356

8. Barnett JR, Bonham VA (2004) Cellulose microfibril angle in the cell wall of wood fibres. Biol Rev Camb Philos Soc 79(2):461-472. https://doi.org/10. 1017/s1464793103006377

9. Alonso B, Guillermo T, Watt MS (2016) Wood properties of juvenile and mature wood of Pinus radiata D. Don trees growing on contrasting sites in chile. For Sci 63(2):184-191. https://doi.org/10.5849/forsci.16-060

10. Lasserre JP, Mason EG, WattMS MJR (2009) Influence of initial planting spacing and genotype on microfibril angle, wood density, fibre properties and modulus of elasticity in Pinus radiata D Don corewood. For Ecol Manage 258(9):1924-1931. https://doi.org/10.1016/j.foreco.2009.07.028

11. Cown DJ, Ball RD, Riddell MJC (2004) Wood density and microfibril angle in 10 Pinus radiata clones: Distribution and influence on product performance. NZ J For Sci 34(3):293-315

12. Watt MS, Sorensson C, Cown DJ, Dungey HS, Evans R (2010) Determining the main and interactive effect of age and clone on wood density, microfibril angle, and modulus of elasticity for Pinus radiata. Can J For Res 40(8):1550-1557. https://doi.org/10.1139/X10-095 
13. Horvath B (2009) Effect of lignin content and structure on the anatomical, physical and mechanical properties of genetically engineered aspen trees. Dissertations \& Theses-Gradworks.

14. Takeuchi R, Wahyudi I, Aiso H, Ishiguri F, Istikowati WT, OhkuboT, (2019) Anatomical characteristics and wood properties of unutilized artocarpus species found in secondary forests regenerated after shifting cultivation in central Kalimantan, Indonesia. Agrofor Syst 93(2):745-753. https://doi. org/10.1007/s10457-017-0171-9

15. Chen ML, Zhang SY, Wang CHG (2016) Wood properties of Chinese-fir after biological degradation by Gloeophyllum trabeum (Pers.) murrill (in Chinese). J Anhui Agric Univ 43(3):378-382. https://doi.org/10.13610/j. cnki.1672-352x.20160512.002

16. Fan WJ, Tu DY, Peng CH et al (2015) Influence of heat treatment on mechanical properties of Populus tomentosa wood (in Chinese). J Northeast For Univ 43(10):88-91

17. Damayanti R, llic J, Ozarska B, Pari G, Vinden P (2015) Crystallinity as a non-destructive indicators of wood hardness at standing trees. Appl Mech Mater 771: 232-241. Doi: https://doi.org/10.4028/www.scientific. net/AMM.771.232

18. Via BK, So CL, Shupe TF, Groom LH, Wikaira J (2009) Mechanical response of longleaf pine to variation in microfibril angle, chemistry associated wavelengths, density, and radial position. Compos A Appl Sci Manuf 40(1):60-66. https://doi.org/10.1016/j.compositesa.2008.10.007

19. Ge XW, Wang LH, Hou JJ (2016) Study on the relationship between microstructure, mechanical properties and chemical composition of brown rot poplar (in Chinese). J Beijing For Univ 38(10):112-122

20. Gindl W, Gupta HS, Schöberl T, Lichtenegger HC, Fratzl P (2004) Mechanical properties of spruce wood cell walls by nanoindentation. Appl Phys A 79(8):2069-2073. https://doi.org/10.1007/s00339-004-2864-y

21. Gindl W, Gupta HS, Grünwald C (2002) Lignification of spruce tracheid secondary cell walls related to longitudinal hardness and modulus of elasticity using nano-indentation. Can J Bot 80(10):1029-1033. https:// doi.org/10.1139/b02-091

22. SAC (2009) GB/T 1936.1-2009. Method of testing in bending strength of wood (in Chinese). Standards Press of China, Beijing

23. SAC (2009) GB/T 1936.2-2009. Method for determination of the modulus of elasticity in static bending of wood (in Chinese). Standards Press of China, Beijing

24. SAC (2009) GB/T 1935-2009. Method of testing in compressive strength parallel to grain of wood (in Chinese). Standards Press of China, Beijing

25. Andersson S, Serimaa R, Paakkari T, Saranp ̈̈̈̈ P, Pesonen E (2003) Crystallinity of wood and the size of cellulose crystallites in Norway spruce (Picea abies). J Wood Sci 49(6):531-537. https://doi.org/10.1007/ s10086-003-0518-x

26. Paakkari T, Blomberg M, Serimaa R (1988) A texture correction for quantitative $X$-ray powder diffraction analysis of cellulose. J Appl Crystallogr 21(5):393-397

27. Cave ID (1997) Theory of X-ray measurement of microfibril angle in wood. Wood Sci Technol 31(3):143-152

28. Andersson S, Serimaa R, Torkkeli M, Paakkari T, Saranpää P, Pesonen E (2000) Microfibril angle of Norway spruce [Picea abies (L.) Karst.] compression wood comparison of measuring techniques. J Wood Sci 46:343-349. https://doi.org/10.1007/BF00776394

29. Sharma M, Apiolaza LA, Chauhan S, Mclean JP, Wikaira J (2015) Ranking very young Pinus radiata families for acoustic stiffness and validation by microfibril angle. Ann For Sci 73(2):393-400. https://doi.org/10.1007/ s13595-015-0529-y

30. Ayobi E, Kiaei M, Bakhshi R (2011) Heartwood and sapwood properties of Quercus castaneaefolia in the Iranian forests. Middle East J Sci Res 8(3):669-673

31. Xia LM, Qi JQ, Huang XY (2018) Physical-mechanical properties of heartwood and sapwood in Toona sp. wood (Toona ciliata M. Roem.) before and after accelerated aging treatment. BioResources 13(4):8409-8420. https://doi.org/10.15376/biores.13.4.8409-8420

32. Tembe ET, Ekhuemelo DO, Ujah C (2018) Variation in density and some strength properties of sapwood and heartwood of Afzelia Africana Sm. ex Pers. and Daniella oliveri (Rolfe) Hutch. and Dalz. in Makurdi, Nigeria. Res J Agric For Sci 6(12):1-6

33. Cato S, Mcmillan DL et al (2006) Wood formation from the base to the crown in Pinus radiata: gradients of tracheid wall thickness, wood density, radial growth rate and gene expression. Plant Mol Biol 60(4):565-581. https://doi.org/10.1007/s11103-005-5022-9

34. Evans R, Geoffrey D, Menz D, Stringer S (1995) Rapid measurement of variation in tracheid transverse dimensions in a Pinus radiata tree. Appita J 48:134-138

35. Rongjun Z, Chunli Y, Xianbao C, Jianxiong L, Benhua F, Yurong W (2014) Anatomical, chemical and mechanical properties of fast-growing Populus x euramericana cv. '74/76.' IAWA J 35(2):158-169. https://doi.org/10.1163/ 22941932-00000057

36. Hill SJ, Grigsby WJ, Hall PW (2013) Chemical and cellulose crystallite changes in Pinus radiata during torrefaction. Biomass Bioenerg 56:92-98. https://doi.org/10.1016/j.biombioe.2013.04.025

37. Sun X, Zhang S, Lai M, Sun C (2017) Age-related trends in genetic parameters for wood properties in Larix kaempferi clones and implications for early selection (in Chinese). Front Agric Sci Eng 4(4):482-492. https://doi. org/10.15302/j-fase-2017184

38. Wu Y, Zhou DG, Wang SQ (2009) Relationship of wood MFA and density with elastic modulus (in Chinese). J Nanjing For Univ (Nat Sci Edn) 33(4):113-116. https://doi.org/10.3969/j.issn.1000-2006.2009.04.024

39. Donaldson $L$ (2008) Microfibril angle measurement, variation and relationships—a review. IAWA J 29(4):345-386. https://doi.org/10.1163/ 22941932-90000192

40. Brennan M, McLean JP, Altaner CM, Ralph J, Harris PJ (2012) Cellulose microfibril angles and cell-wall polymers in different wood types of Pinus radiata. Cellulose 19(4):1385-1404. https://doi.org/10.1007/ s10570-012-9697-1

41. Yang S, Chen Y, Yan T (2019) Effect of heat-treatments on chemical properties of imported Pinus Radiata wood (in Chinese). China Wood Industry 33(5):44-48. https://doi.org/10.19455/j.mcgy.20190510

42. Agarwal UP, Ralph SA, Baez C, Reiner RS, Verrill SP (2017) Effect of sample moisture content on XRD-estimated cellulose crystallinity index and crystallite size. Cellulose 24(5):1971-1984. https://doi.org/10.1007/ s10570-017-1259-0

43. Via BK, So CL, Shupe TF, Groom LH, Wikaira J (2009) Mechanical response of longleaf pine to variation in microfibril angle, chemistry associated wavelengths, density, and radial position. Compos Part A Appl Sci Manuf 40(1):60-66. https://doi.org/10.1016/j.compositesa.2008.10.007

44. Donaldson LA, Singh AP (1998) Bridge-like structures between cellulose microfibrils in radiata pine (Pinus radiata D. Don) Kraft Pulp and Holocellulose. Holzforschung 52(5):449-454

45. Salmén L, Burgert I (2009) Cell wall features with regard to mechanical performance. A review COST Action E35 2004-2008: wood machiningmicromechanics and fracture. Holzforschung 63(2):121-129. https://doi. org/10.1515/hf.2009.011

46. Vanholme R, Morreel K, Ralph J, Boerjan W (2008) Lignin engineering. Curr Opin Plant Biol 11(3):278-285. https://doi.org/10.1016/j.pbi.2008.03.005

47. Takeshi Fujino TI (1998) Changes in the three dimensional architecture of the cell wall during lignification of xylem cells in Eucalyptus tereticornis. Holzforschung 52(2):111-116

\section{Publisher's Note}

Springer Nature remains neutral with regard to jurisdictional claims in published maps and institutional affiliations. 